\title{
W krainie światła, w krainie Cienia. Nad prozą autobiograficzną Faruka Šehicia
}

\begin{abstract}
Bukwalt Miłosz, W krainie światta, w krainie Cienia. Nad proza autobiograficzna Faruka Šehicia (The Land of Light, the Land of Shadow. About the Autobiographic Prose of Faruk Šehić). "Poznańskie Studia Slawistyczne" 16. Poznań 2019. Publishing House of the Poznań Society for the Advancement of the Arts and Sciences, Adam Mickiewicz University, pp. 69-87. ISSN 2084-3011
\end{abstract}

This article is the first attempt in Poland to examine the following issues in The Book of Una, the novel by Faruk Šehić: the problems of autobiographic memory, war trauma, going through the trauma situation in a creation process (autobiography as a symbol of individual identity and an attempt to overcome the stressor). The analysis drew attention to the category of a journey into the depths of one's self within the so-called past life regression present in the work by this Bosnian author. In the course of the examination, it was revealed that the intimate contact established by and between the protagonist with the important figures from his childhood, sentimental objects, the aquatic element, plant world and places of playing, adventure and shelter has a therapeutic dimension.

The aforementioned issues were studied with the use of a set of scientific tools in the area of anthropology of culture (abjective experiences and objects, symbolism of blood, category of childhood), theory of trauma, hypnology and hyperesthesia, polemology, humanistic psychiatry, Bachelard's theory of poetic image, topoanalysis and poetics of the elements. The process of interpretation also included the Jungian concept of structure of personality known as the Shadow archetype.

KeYwords: trauma; hypnosis; memory; childhood; rivers; ichthiofauna; fishing; family home; war; death; Shadow

Autobiograficzna pamięć rozpadu państwa, wojny ${ }^{1}$, domu rodzinnego, artefaktów nostalgicznych, świata przyrody, miejsc oswojonych w przestrzeni rustykalnej i urbanistycznej stanowi fundament, na którym Faruk

\footnotetext{
${ }^{1} \mathrm{Na}$ temat boszniackich twórców spod znaku literatury wojennej (ratno pismo) i poetyki świadectwa (poetika svjedočenja) v. Kodrić, 2012, 174-201.
} 
Šehić, boszniacki prozaik, poeta i felietonista, buduje świat przedstawiony debiutanckiej powieści Książka o Unie (Knjiga o Uni, 2011)². Przypomnijmy, że pamięć autobiograficzna, definiowana jako „dotychczasowe doświadczenie życiowe", odpowiada za kodowanie, przechowywanie oraz odtwarzanie zdarzeń z przeszłości jednostki ludzkiej (Maruszewski, 2005, $31,18)$. Do podstawowych form pamięci autobiograficznej zaliczamy pamięć okresów życia (informacje dotyczą w tym przypadku ważnych osób, form aktywności oraz jednostkowych celów i planów), zdarzeń o charakterze ogólnym oraz przeżyć specyficznych (Maruszewski, 2005, 65). Wśród naczelnych funkcji tego typu pamięci wymienić należy: regulowanie relacji z otoczeniem, komunikowanie innym informacji na własny temat, wytwarzanie i wzmacnianie, w procesie wspólnego odpamiętywania, więzi międzyludzkich. Materiał zgromadzony w indywidualnym „magazynie pamięci” formuje osobowość i tożsamość człowieka oraz wpływa na kształt jego relacji z innymi ludźmi. Podkreślmy przy tym, że procesowi eksploracji przeszłości towarzyszy zwykle zjawisko interpretacji, tj. zniekształcania poszczególnych śladów pamięci (Maruszewski, 2005, 32).

Dokonana przez Faruka Šehicia pamięciowa rekonstrukcja faktów z własnej przeszłości przybiera ostatecznie gatunkową postać autobiografii retrospektywnej o dużym ładunku lirycznym. Konstruowanie wspomnień autobiograficznych tożsame jest, jak przekonuje Georges Gusdorf, z „odtworzeniem i odczytaniem” własnego życia, zebraniem „rozproszonych elementów losu", utrwaleniem własnego wizerunku, odzyskaniem rzeczy pozornie utraconych oraz, co ważne, przezwyciężeniem śmierci i zapomnienia. Utwór autobiograficzny, daleki od prawdy faktów, „niepełny” i „skażony” przez zawodną pamięć, stanowi próbę budowania osobowej legendy i mitologii (Gusdorf, 1979, 263, 270-271). Nadając nowy sens i koloryt światu ludzkich doświadczeń i emocji, autobiografia, raz jeszcze

\footnotetext{
${ }^{2}$ Na dorobek artystyczny Faruka Šehicia (ur. w Bihaciu w roku 1970) składają się utwory liryczne opublikowane w zbiorach Pjesme u nastajanju (2004), Hit Depo (2003), Pod pritiskom (2004) oraz Moje rijeke (2014). Ostatni z tomików przyniósł autorowi prestiżową międzynarodową Nagrodę Literacką im. Risto Ratkovicia. Wśród utworów prozatorskich Faruka Šehicia wymienić należy przetłumaczoną na kilka języków europejskich powieść Knjiga o Uni (2011), za którą pisarz otrzymał Europejską Nagrodę Literacką oraz Nagrodę im. Mešy Selimovicia. Utwór ten zyskał także nominację do Nagrody Literackiej Europy Środkowej „Angelus” (Wrocław, 2017). W roku 2018 Šehić opublikował tom krótkiej prozy pod tytułem Priče sa satnim mehanizmom (2018).
} 
przywołajmy słowa francuskiego filozofa i epistemologa, tworzy zatem zupełnie „nową modalność bytu” (Gusdorf, 1979, 270).

Akt tworzenia autobiografii stanowi w przypadku Šehicia próbę odreagowania sytuacji traumatycznych ${ }^{3}$, wśród których za ważne uznać można: czynny udział w konflikcie zbrojnym, okaleczenie, zadawanie śmierci innym osobom czy też utratę domu rodzinnego i przedmiotów osobistych. Odczuwaną przez pisarza wewnętrzną potrzebę przepracowania zdarzeń traumatyzujących w procesie twórczym w pełni wyraża fragment:

We wszystkich moich ranach okropnie teraz leje. Rozmaite stworzenia i opowieści chcą się ze mnie wydostać, aby uciec przed nadciągającym potopem. Musiałem zacząć ratować to, co się dało. Słowa, stylistyczne figurki, szkice, istoty takie jak niedorzeczny Gargano, przedmioty - wszystko to należało załadować na stabilny okręt. [...] Statek nazwałem ostatecznie Ksią̇ka o Unie. [...] Spośród wszystkich rządzących mną wątpliwości, pewien jestem jedynie powodu, dla którego powstała ta książka. [...] Miałem nadzieję, że poprzez opisywanie uda mi się doprowadzić do tego, że moje przedmioty ze świata osaczającego mnie niczym mroczny las zyskają odporność i niezniszczalność. Postanowiłem słowami odbudować wszystko to, co - jak mi się wtedy wydawało - ulotniło się już na zawsze. [...] Dzięki pisaniu mogłem stworzyć protezę, zastępczy świat. [...] Kiedy dotknąłem już świętych przedmiotów z przeszłości i odzyskałem swą spójność, ogarnął mnie ponownie niepokój. Uświadomiłem sobie, że poza wojną oraz wywołanymi przez nią zaburzeniami czasu i przestrzeni istnieją jeszcze inne przyczyny traumy. Przyczyną jest również układ moich nerwów, miniaturowych czułków rozsianych po całym ciele. Pojąłem, że piszę książkę o melancholii, która będzie jak tarcza ze świetlnymi słowami (Šehić, 2016, 173-175, 177, 179).

Z traumą, czego dowodzi powyższe wyznanie (nosi ono, co warto podkreślić, wyraźne cechy refleksji autotematycznej) ${ }^{4}$, można zmierzyć się w procesie twórczym. Dzieje się tak, gdyż jak zauważa Justyna

${ }^{3}$ Do podstawowych zdarzeń traumatyzujących psycholożka Maja Lis-Turlejska (2005, 22) zalicza: niespodziewany atak z zewnątrz, ciężkie pobicie, gwałt, nieoczekiwany zgon bliskiej osoby, bezpośredni udział w konflikcie zbrojnym, zranienie, torturowanie, przebywanie w niewoli, porwanie, doświadczenie klęski żywiołowej, utraty domu, zagrażającej życiu choroby jak również znalezienie martwego ciała, czy też bycie świadkiem zabicia i okaleczenia innej osoby.

${ }^{4}$ Powieść Faruka Šehicia zawiera liczne komentarze odautorskie. Autor wtajemnicza odbiorcę w proces tworzenia utworu. Ten, który, by rzec słowami Artura Sandauera (1981, 464), „widzi powieść i ją wymyśla” ujawnia dylematy związane z wyborem tytułu i tematu dzieła, wskazuje także na ocalającą i terapeutyczną moc słowa pisanego. Na uwagę zasługują także liczne, odautorskie odniesienia i aluzje do znanych dzieł literackich, muzycznych czy filmowych. 
Tabaszewska, trauma „wyrażona i opisana przez doświadczający ją podmiot przestaje nią być. Ujęcie w narracyjne ramy sprawia, że siła jej oddziaływania niemal maleje, zmieniając się jedynie w relację o przeszłości” (Tabaszewska, 2011, 13-14). Kształtowana za pomocą różnorodnych środków wyrazu opowieść o zdarzeniu traumatycznym stanowi, co należy podkreślić, rodzaj artystycznego projektu. Nie sposób bowiem wyrazić w pełni doświadczenia urazowego na gruncie literatury czy szeroko rozumianej sztuki. Trauma w literaturze staje się zatem kategorią estetyczną, która niczego nie objawia, a jedynie wywołuje u odbiorcy określone reakcje intelektualne oraz emocjonalne w postaci współodczuwania, zdziwienia, niedowierzania, oburzenia, empatycznego gniewu czy też szoku (Tabaszewska, 2011, 15). Należy dodać, że przywołując w swym utworze sytuację traumatyzującą, twórca wybiera strategię odrzucenia teraźniejszości, zamknięcia się na świat zewnętrzny i funkcjonowania wyłącznie w sferze zdarzeń minionych (Tabaszewska, 2011, 15-16).

Niniejszy artykuł stanowi pierwszą na gruncie polskim próbę zbadania kluczowych dla powieści Faruka Šehicia Książka o Unie problemów pamięci autobiograficznej, odpamiętywania, traumy wojennej, przepracowania sytuacji urazowej w procesie twórczym (autobiografia jako znak jednostkowej tożsamości i próba przezwyciężenia stresora). W trakcie analizy zwrócono uwagę na obecną w utworze bośniackiego autora kategorię podróży w głąb siebie w ramach tzw. hipnotycznej regresji wcieleń. Jak wykazano, nawiązanie ponownego kontaktu z ważnymi postaciami dzieciństwa, żywiołem akwatycznym, światem roślinnym, a także miejscami zabawy, przygody i schronienia, posiada w przypadku protagonisty badanego utworu wymiar terapeutyczny.

Powyższe zagadnienia zbadano w oparciu o instrumentarium z zakresu antropologii kulturowej (doznania i obiekty abiektywne, symbolika krwi, kategoria dzieciństwa), teorii traumy, hipnologii i hiperstezji, polemologii, psychiatrii humanistycznej, Bachelardowskiej teorii obrazu poetyckiego, topoanalizy i poetyki żywiołów. W procesie interpretacji wykorzystano także zaproponowaną przez Carla Gustva Junga koncepcję struktury osobowości (archetyp Cienia).

Powieść Faruka Šehicia przywołuje traumatyczne zdarzenia z okresu istnienia Titowskiej Jugosławii, momentu dekompozycji federacyjnego państwa oraz konfliktu zbrojnego w Bośni i Hercegowinie z lat 
1991-19955. Utrwalony w pamięci narratora-bohatera (w utworze występuje on pod nazwiskiem Mustafa Husar) obraz jugosłowiańskiej rzeczywistości opatrzony zostaje negatywnym znakiem wartościującym. Opisowi elementów świata spod znaku „braterstwa i jedności” towarzyszy bowiem uczucie dojmującego wstrętu, a więc ,jednego z najbardziej gwałtownych afektów, do jakich jest zdolny ludzki system percepcji” (Mennighaus, 2009 , 7). Emblematem państwa (w utworze przyrównane zostaje ono do kloaki ${ }^{6}$ ), jego represyjnych instytucji oraz przestrzeni życia prywatnego stają się, budzące odruch wymiotny ${ }^{7}$, elementy taediogenne w postaci odorów uryny, ludzkich i zwierzęcych wydalin, a także widoku postkoitalnych odpadków. Narrator, zdeklarowany przeciwnik ${ }^{8}$ komunistycznego porządku społeczno-politycznego, wyznaje:

Moje wspomnienia są brudne i ohydne. Odczuwam wstręt, kiedy muszę mówić o byłym państwie i początku wojny. Tak jak wtedy, gdy chłopcy z biednych rodzin śmierdzą szczynami w szatni przed lekcją WF-u. Na widok szkolnego budynku zimny pot mnie oblewa pod swetrem, zaczynam się dusić tak bardzo, że natychmiast dostaję ataku klaustrofobii. Ratunek przed nadmiarem wojskowej dyscypliny znajdowaliśmy w szkolnej toalecie, gdzie stężenie amoniaku ścinało oddech. [...] W muszlach toaletowych pływały niedopałki i prezerwatywy, jedyna widoczna oznaka buntu przeciw bezwzględnemu systemowi. [...] Zbutwiałe drewniane podłogi austro-węgierskich domów cuchną stęchłymi odchodami i chorobami lokatorów, miejskiego lumpenproletariatu. [...] Wspomnienia są tak brzydkie, że uniemożliwiają same siebie. Wszystko, co

${ }^{5} \mathrm{~W}$ trakcie trwania konfliktu bośniackiego podporucznik Faruk Šehić dowodził stutrzydziestoosobowym oddziałem muzułmańskich ochotników. Grupa ta wchodziła w skład V Korpusu Armii Bośni i Hercegowiny, walczącego na terenie północno-zachodniej Bośni. Obszar działań operacyjnych tej formacji stanowiła Bosanska Krajina. Wskutek odniesionych ran wojennych Faruk Šehić został przeniesiony w stan spoczynku.

${ }^{6}$ Terminu Cloaka Maxima używa także Vladimir Arsenijević na określenie wojennej rzeczywistości Nowej Jugosławii.

${ }^{7}$ Dla nazwania tego, co „wstrętne [abject]”, Julia Kristeva $(2007,7,9)$ używa właśnie terminu „wy-miot”. Badaczka stwierdza: „odraza do jedzenia, brudu, odpadów, kału. Bronią mnie skurcze i wymioty. Obrzydzenie, mdłości odsuwają mnie i odwracają od nieczystego, od szamba i plugastwa".

${ }^{8}$ Jak zauważa Winfried Mennighaus (2009, 7, 9), ,gdy odczuwamy wstręt, wszystko wydaje się zagrożone. Wstręt jest stanem alarmowym i stanem wyjątkowym, ostrym kryzysem w obliczu niedającej się asymilować inności, konwulsją i walką, w której literalnie chodzi o «być albo nie być». [...] Działanie obronne wstrętu oznacza, w wysoce abstrakcyjnym sformułowaniu, spontaniczną i szczególnie mocną negację. [...] Wstręt implikuje wszakże nie tylko zdolność negowania, lecz także konieczność negowania [podkr. aut.] - kto odczuwa wstręt, nie jest zdolny nie negować". 
sobie przypominam, podpowiada mi, żebym przerwał tę zawracającą opowieść. Widzę końskie gówna parujące na asfalcie ulicy Tita. Stukot kopyt, niestrudzony, depresyjny takt, który odbiera mi odwagę. Deszcz padający całymi dniami w rytm podków. Wiem, że potrafię pokonać to uczucie mdłości i że byłbym w stanie zobaczyć świat w piękniejszych kolorach, ale wydaje mi się, że zawiódłbym swoją własną tęsknotę za bezkompromisowym spojrzeniem na przeszłość. [...] Moja odraza mogłaby przybrać formę religii, ale nie chcę się pogrążyć w nienawiści, to byłoby, jak na mój gust, zbyt tandetne. W słońcu jest za gorąco, w cieniu zimno i wilgotno. Śmierdzi moczem, kałem, pastą do butów. Takie są moje wspomnienia z minionego życia, te, które jako pierwsze przewijają się przed oczyma (Šehić, 2016, 7-9)

Do zdarzeń traumatyzujących, które odciskają trwały ślad w psychice narratora, zaliczyć należy także czynny udział w bośniackim konflikcie wojennym po stronie muzułmańskiej. W porządku wojny, jak zauważa Barbara Eihenreich (1997, 18), poszczególne społeczności „wkraczają w odmienny obszar ludzkiego doświadczenia”. Warunki wojenne przywodzą zatem na myśl sytuację odejścia od przyjętych norm moralnych i zwyczajowych. W sytuacji odwróconego porządku (,żywiołu”) czymś zwykłym wydają się zatem akty przemocy w postaci kradzieży, zabijania, gwałtu, czy palenia dobytku9 . Agresywne zachowania mężczyzny przeobrażonego w wojownika zyskują zatem odpowiednią sankcję społeczną (Eihenreich, 1997, 17-19).

W rozważaniach narratora na plan pierwszy wysuwa się przede wszystkim strategia „fizycznego przetrwania” (Šehić, 2016, 10). Zachowania bohatera warunkuje pierwsze prawo biologiczne związane z ocaleniem własnego życia. $Z$ powyższym prawem związane są przede wszystkim negatywne uczucia nienawiści, okrucieństwa oraz agresji wobec istoty, która winna zostać zniszczona, a także uczucie lęku przed obcym, który może zadać śmierć. Przyjęcie postawy obronno-repulsywnej wobec wrogiego świata oznacza zawsze mobilizację ustroju oraz podszytą lękiem biologicznym gotowość do podjęcia walki lub ucieczki. Zadawanie śmierci wyklucza możliwość wystąpienia reakcji empatycznych wobec ofiar (Kępiński, 2004, 191, 197, 269). Zabijanie innego stanowi, jak zauważa Charles Baudelaire $(1997,50)$, nieodłączny przywilej wojownika, a więc

${ }^{9}$ Francuski etnolog Roger Caillois (1973, 160-168) postrzega wojnę jako stan świętowania, społeczny „paroksyzm”, z typowymi dlań sytuacjami ,wybryku, gwałtu, przebierania miary i radości niszczenia”. 
istoty „wielkiej” i godnej najwyższego szacunku. Zafascynowany „upuszczaniem krwi" ${ }^{10}$ narrator-bohater stwierdza:

Ludzie, muszę się przyznać, zabiłem człowieka, i to nie tylko jednego. Kiedy strzelasz, nie jesteś niczym obciążony. Co prawda nie każda kula trafia, ale niektóre z pewnością dosięgają celu. Kiedy strzelasz, jesteś lekki jak piórko i z tego zadowolenia mógłbyś w okamgnieniu oderwać się od ziemi, wznieść się, ale przecież właśnie się kryjesz, całym ciężarem ciała napierasz brzuchem na rozgrzebaną ziemię, podeptaną trawę, mokre liście, bo tak podpowiada ci instynkt. Kiedy strzelam, czuję się jak Dżizas Anty-chryst. Doręczam jedynie przeciwieństwo miłosierdzia. Wyrzuty sumienia nie istnieją i nikt ci nie szepnie na ucho: nieprzyjaciel to też istota ludzka. Na froncie sprawy przedstawiają się inaczej: nieprzyjaciel to nieprzyjaciel. On nie może być istotą ludzką. [...] Zabiłem trzy osoby, i jednego autonomistę. [...] Żywe ciała przemieniałem w cienie. W cienie nocnych motyli, czyli w nic. Zabijałem na frontach o zapomnianych i mało znaczących nazwach, we wszystkich warunkach pogodowych [...]. Nie gryzie mnie sumienie z powodu tych ludzi, których teraz wyobrażam sobie jako widmowe portrety na fotografiach, bez wyciętych nożyczkami głów. [...] Jeszcze chwila i z mojej pamięci osuną się w ciemność. [...] Zabijałem, ponieważ chciałem istnieć dłużej niż Chaos. A także dlatego, ponieważ nie znałem innego sposobu na ocalenie (Šehić, 2016, 11-12).

W utrwalonych w pamięci obrazach wojny powraca także typowy dla konfliktu bośniackiego rytuał „zabijania miasta" ${ }^{11}$ oraz strategia spalonej ziemi, której cel stanowi grabież i niszczenie infrastruktury społecznej oraz przemysłowej. Masową kradzież oraz zacieranie śladów wcześniejszego pobytu elementów obcych etnicznie na terytorium kontrolowanym przez wspólnotę muzułmańską bohater określa eufemistycznie jako „dziwną i powszechną dolegliwość" (Šehić, 2016, 15).

Swoistą formę terapii stresu pourazowego ${ }^{12}$, którego ofiarą pada protagonista powieści, stanowi seans hipnotyczny. Przypomnijmy w tym

${ }^{10}$ Jak zauważa Jean-Paul Roux, widok przelewanej krwi budzi dychotomiczne uczucia „przyciągania” i „odpychania”. Krew bowiem ,wzbudza odrazę, lecz ta odraza schodzi na dalszy plan, nawet, a zwłaszcza wtedy, gdy nieodparcie przywołuje obrazy cierpienia i śmierci. [...] Krew niesie w sobie siłę emocjonalną niejako spontaniczną, czysto instynktowną, często niezależną od jakichkolwiek świadomych skojarzeń, siłę, od której nikt nie potrafi uciec" (Roux, 2013, 30-32).

${ }^{11} \mathrm{Na}$ temat barbarzyńskiej praktyki urbicydu v. Bogdanović, 1997, 27-33.

${ }^{12}$ Do podstawowych symptomów stresu pourazowego (posttraumatic stress disorder) Peter A. Levine i Ann Frederic zaliczają: „retrospekcje (odtwarzanie w pamięci przeżyć z przeszłości), niepokój, lęk, ataki paniki, bezsenność, depresję, dolegliwości psychosomatyczne, skrytość, niesprowokowane brutalne ataki wściekłości oraz powtarzające się zachowania destrukcyjne" (Levine, Frederick, 2012, 51). 
miejscu, że hipnoza jest tymczasowym stanem odmiennej świadomości człowieka (tzw. jasny lub sztuczny sen), którą wywołuje hipnotyzer. Podatność jednostki na indukcję hipnotyczną zależy od siły motywacji pacjenta, znajomości metody, stopnia wiary w jej skuteczność oraz raportu, tj. jakości relacji hipnotyka z terapeutą. Pod wpływem określonych heterosugestii słownych lub fiksacyjnych (wpatrywanie się w przedmiot lub twarz hipnotyzera) hipnotyk, na różnych poziomach transu, może doświadczać stanu katalepsji, analgezji, parestezji, halucynacji lub częściowej amnezji. W trakcie seansu osoba hipnotyzowana wypowiada także specyficzne komunikaty werbalne (Augustynek, 1989, 4; Peterson, 1994, 34-35). To właśnie nieskrępowana werbalizacja, określana także „rozładowaniem słownym", prowadzi do zmniejszenia napięcia, uwolnienia tłumionych konfliktów wewnętrznych, złagodzenia poczucia winy oraz uzyskania kontroli nad emocjami (Wolberg, 1975, 262-263).

Do najważniejszych zjawisk z zakresu hipnozy zaliczyć należy regresję, tj. ,zdolność pacjenta do zawrócenia wskazówek zegara i do odegrania ponownie, jak gdyby z zapisu na taśmie, wydarzeń i wyobrażeń z okresu wczesnego dzieciństwa lub innych etapów życia" (Wolberg, 1975, 201-202). Jako stan psychofizyczny regresja hipnotyczna pozwala zatem przywołać i ożywić przyjemne bądź traumatyczne ślady pamięciowe z różnych poziomów rozwoju jednostki. W procesie przypominania powracają konkretne miejsca, osoby a także ważne dlań zdarzenia. Hipnotyczna podróż w głąb siebie staje się zatem nieocenionym źródłem samowiedzy. Pozwala ona przede wszystkim na podniesienie poczucia własnej wartości, poszerzenie świadomości, odkrywanie i nazywanie uczuć, wzrost pewności siebie, zwiększenie samozaufania oraz zrzucenie ciężaru negatywnych doświadczeń (Kaczorowski, 2008, 30).W literaturze przedmiotu wyprowadzenie $\mathrm{z}$ transu hipnotycznego przez usunięcie sugestii nosi nazwę dehipnotyzacji. Wśród uczuć wyniesionych z seansu wymienia się doznanie niezwykłości, rozluźnienia, lekkości, odprężenia, bycia w innym świecie, roztopienia w przestrzeni oraz odłączenia od własnego ,ja” (Kropikiewicz, 1992, 174).

Ukazana w utworze sesja nosi cechy hipnozy estradowej, a więc pokazu, który jako źródło masowej rozrywki prowadzi do „psychicznego obnażenia się i wystawienia [osoby hipnotyzowanej] na widok publiczny" (Wolberg, 1975, 295). Hipnoza, zastosowana jako metoda widowiskowa prowadzi wyłącznie do rozbawienia, olśnienia czy zaintrygowania 
publiczności. Stosunek hipnotyzera do hipnotyka pozbawiony jest w takim przypadku zabarwienia emocjonalnego (Kropikiewicz, 1992, 181). W powieści Šehicia przestrzeń pokazu stanowi sala kinowa odnowionego (na jej ścianach łatwo jednak dostrzec ślady zdrapanych „świętych sloganów” partyjnych) po wojnie domu kultury. Rolę medium zapewnia zaś bohaterowi przecinająca twarz wojenna rana-piętno, swoisty „,bilet wstępu” na widowisko pozbawione oprawy, powagi i godności. W przebiegu zdarzenia odnotowujemy elementy typowe dla sensu hipnotycznego w postaci sugestii słownych hipnotyzera, indukcji, raportu, transu, „rozładowania słownego", katalepsji i regresji wieku. Potwierdza to cytat:

Nie miałem pojęcia, dlaczego fakir wybrał właśnie mnie. [...] Z nieba niespodziewanie spadłem mu ja, początkujący poeta i weteran naszej miłej wojny. [...] Fakir wskazał na mnie palcem, zgasił latarkę i zniknął w czarnym jak węgiel mroku. Serce zaczęło mi rytmicznie łomotać. Niecodzienne wyzwania przyjmowałem zawsze z zadowoleniem. Im bardziej szalone, tym lepiej. [...] Jak już wiecie, oś czasu pomiędzy przed i powojennym życiem pękła, ponad tą nieciągłością należało przerzucić most. Będę musiał zostać podróżnikiem w czasie i wyruszyć wstecz. Przelecieć nad wojną, chociaż to niemożliwe, i przezwyciężyć własne mdłości. Odnaleźć oś czasu i połączyć ją z obecnym momentem. Ponieważ pragnę być całością, choćby tylko we własnej pamięci. [...] Na scenę wkracza hipnotyzer, na głowie ma turban pełen syczących zobojętniale żmijek. [...] Za każdym razem, kiedy wypowiadał cyfrę, tsunami myśli układało w sensowne całości, przerabiane następnie na zdania spowiedzi. Miałem wierną publiczność, której mogłem godzinami opowiadać o wszystkim i o niczym, ale to było doświadczenie innego rodzaju. Jestem jak pokrętło na urządzeniu do odgadywania ludzkich losów, trzeba mnie tylko przełączyć, jestem lunetą natury, okularem, tubą i lupą skrzyżowaną z długoszyim storczykiem. Przez jego trąbkę będę wyrzucał historie. [...] Sztuczna mgła połyka mnie z zawrotną prędkością. Zapadałem się w czas jak w miękki torf. [...] Mogłem do woli zmieniać lata i dekady. [...] Mgła spowiła mnie od nóg po szyję, zatrzymując się na wysokości kołnierzyka. Powiem wszystko, nawet to, o co fakir nie pyta (Šehić, 2016, 16-20).

Wywołana w prawdziwie „cyrkowych” warunkach regresja hipnotyczna umożliwia jednak bohaterowi powrót do wczesnego etapu życia ${ }^{13}$. Przywołane przezeń wspomnienia zostają zdominowane przez, rozumiane

${ }^{13}$ Jak zauważa boszniacka badaczka Selma Raljević (2014, 45-46), „Šehićev roman ostvaruje se kao vertigo stvarnosti i snova, ljepote i užasa, prirode i grada, te sreće i nesreće, mira i rata, života i smrti. Stabilnost i cjelovitost unutar tog vertiga nastoji se pronaći umjetničkim postupkom hipnoze nestabilnog i podijeljenog subjekta. Psihogramskim narativom hipnotizirane svijesti, na principu asocijacija, u post-ratni tok sadašnjosti romana slijevaju se struje sjećanja prijeratne i ratne prošlosti jednog čovjeka. Vertigo upravo i tvore tokovi prošlosti, sadašnjosti i vizija o budućnosti u jedinstvu vremena «sada». Vrijeme je cjeloviti 
jako ważne znaki tożsamości, liryczne obrazy i werbalizacje z dzieciństwa. Dzieje się tak, gdyż jak zauważa Gaston Bachelard, każde marzenie zwrócone ku dzieciństwu pogłębia u podmiotu marzącego „świadomość źródła". Przywołane obrazy początków jednostkowej egzystencji pozbawione są temporalnej miary i faktograficznego balastu. Wszelka bowiem historyczność, podkreśla francuski fenomenolog, przeszkadza marzycielowi w uświadomieniu sobie „,ciągłości ośrodka dzieciństwa”. Pozbawione dat i odspołecznione rojenie o ,pierwocinach życia” kieruje się zatem nie ku datom, liczbom, czy konkretnym zdarzeniom z przeszłości, lecz ku rytmom pór roku, które, „kręcąc się po niebie dzieciństwa, w każdym dzieciństwie pozostawiają niezatarte znaki" (Bachelard, 1998, 31, 114, 132, 136). W „kosmicznych” marzeniach o dziecięctwie (są to prawdziwe, jak zapewnia badacz, „wszechświaty szczęścia”) ożywają także podstawowe archetypy rozumiane jako ,źródła potężnych poetyckich obrazów”. Do najważniejszych z nich autor Poetyki marzenia zalicza: archetyp „ojcowskich i matczynych mocy”, domu rodzinnego jako „drzewa” ludzkiego losu, doznań olfaktorycznych i wizualnych olśnień, które stają się „korzeniem świata [i] prawdą dzieciństwa" (Bachelard 1998, 140, 143, 145, 158).

W hipnotycznej regresji wieku osiowa postać powieści Šehicia odbywa wyobrażoną wędrówkę do źródeł własnej egzystencji. Wśród przywołanych z pamięci fundamentalnych obrazów ,genialnej epoki” dzieciństwa ważne miejsce zajmuje, wpisany w scenerię akwatyczną, dom babci - stały punkt odniesienia, w którym „rozpoczyna się i zatacza swój krąg” niemająca końca podróż hipnotyczna (Šehić, 2016, 20). Przypomnijmy w tym miejscu, że definiowana jako „kryjówka”, środek, oś i obraz ludzkiego świata, siedziba mieszkalna przywodzi na myśl obdarzony sensem obszar ładu, bezpieczeństwa, swojskości i intymności. (Tischner, 1990, 198; Eliade, 1996, 37). Domostwo, podobnie jak i świątynia, reprezentuje typ naznaczonej mocą przestrzeni świętej, w której w sposób regularny spełniane są określone praktyki, rytuały i obrzędy rodzinne (Leeuw, 1978, 441). $\mathrm{Z}$ faktu uporządkowania obszaru domu w planie poziomym i wertykalnym wynika jego podział na określone strefy, z których każda ma „właściwe sobie przeznaczenie, każda jest [też] miejscem rozgrywania się przypisanych

antiutopistički doživljaj prošlosti, sadašnjosti i budućnosti osviješćen dezideologizacijom ratne zbilje i iskustva vječnog ponavljanja istog". 
jej zdarzeń, wynikających z porządku normowanego określonym rytmem życia” (Czermińska, 1978, 233). Jako typ przestrzeni „dośrodkowej” i zamkniętej dom odgranicza (opozycja orbis interior - orbis exterior) mieszkańców od chaotycznej przestrzeni zewnętrznej. Przekroczenie miejsc mediacji w postaci drzwi czy progu domu oznacza natomiast wejście w świat niebezpieczny, pełen zagrażających człowiekowi nadprzyrodzonych mocy (Kowalski, 1998, 85).

Przywołany przez bohatera w hipnotycznym transie jasny obraz domu rodzinnego zyskuje, wzmiankowane powyżej, cechy miejsca „stabilnego, bezpiecznego i niezniszczalnego" (Šehić, 2016, 53). Ta solidna budowla o mocnym spadzistym dachu, ,grubych i ciepłych" murach występuje właśnie w funkcji chronienia podmiotu marzącego. Na poddaszu, w centrum samotności i zadumy, babka, ta „całkiem zwyczajna cudotwórczyni”, odbywa swoje wyimaginowane podróże w, naznaczoną rodzinną tragedią, wojenną przeszłość. Ożywczym źródłem babcinych wspomnień staje się widok przepływającej w pobliżu domostwa rzeki. Obraz wody przywodzi bowiem na myśl przemijanie, nieuchronność ludzkiego przeznaczenia oraz „krzyk” śmierci.

Jako „dziedzina życia zasuszonego” (Bachelard, 1975, 133) poddasze staje się także przechowalnią przedmiotów zapomnianych ${ }^{14}$. Odnalezione w „rupieciarni” artefakty sentymentalne i użytkowe przemawiają do narratora-marzyciela osobliwym językiem zamierzchłych dni, co ilustruje fragment:

Na poddaszu zapach kurzu i [...] pajęczyn pokrywa odtrącone przedmioty. [...] W wąskim pasie wolnej przestrzeni ustawiono w rzędach babcine buty pamiętające jeszcze czasy belle époque. Pod nimi są stare gazety i skrzynka pewnego radioodbiornika. Zaraz po zapadnięciu nocy wstrzymam oddech, by nie obudzić domowników, i usiądę

${ }^{14}$ Wśród czterech obszarów pamięci Jan Assman wyodrębnia „pamięć rzeczy”. Niemiecki egiptolog stwierdza: „Od dawien dawna otaczają człowieka sprzęty codziennego i intymnego użytku. [...] Człowiek projektuje na nie swoje wyobrażenia o celowości, wygodzie i pęknie, rzeczy zaś odzwierciedlają w pewnej mierze swego twórcę, przypominają mu o jego przeszłości, przodkach itp. Rzeczywistość materialna, w której się poruszamy, jest zegarem: wskazując teraźniejszość, odsyła do przeszłości” (Assman, 2015, 36). W podobnym duchu rozumuje Bjornar Olsen. Badacz ten zauważa, iż rzeczy występują przede wszystkim w roli strażników przeszłości i pamięci. Trwałe przedmioty materialne bowiem „czynią przeszłość obecną i dotykalną, stale opierają się reżimowi, który podporządkowuje czas jego popularnemu wizerunkowi jako czegoś chwilowego i nieodwracalnego" - konkluduje norweski archeolog (Olsen, 2018, 86). 
przy radiu. Jeśli przekręcę gałkę w lewo zapali się płytka z nazwami miast. Cieszę się zwłaszcza wtedy, gdy zaświeci miasto o dziwacznej nazwie Wilno, w którym mieszkają na pewno wilgi w żółto-czarnych kubraczkach (Šehić, 2016, 45).

Na niższym poziomie domostwa, w przestrzeni spowitego mrokiem dziecięcego pokoju, bohater nawiązuje kontakt z odległymi galaktykami i ciałami astralnymi. Tu także, ,ziemski astronauta” zanurza się w ,próżni” nocy. Wyobrażony pokój dzieciństwa jest również źródłem refleksji na temat rzeczy bezpowrotnie utraconych. Katalog przedmiotów nostalgicznych tworzą: telewizor marki „Grundig”, który „,reagował na łagodny dotyk”, książki, kasety magnetofonowe, korespondencja „miłosna i błaha”, numizmaty, artefakty ikonograficzne oraz ,rzutnik nr 8 i taśmy w kartonowych pudłach" (Šehić, 2016, 35-36).

Salon, tradycyjne centrum życia towarzyskiego, pełni równolegle funkcję przestrzeni sakralnej, w której babka, osoba ,przestrzegająca zasad boskiej służby" (Šehić, 2016, 50) w sposób regularny i żarliwy oddaje się rytualnym modlitwom (salat). W salonie także, w czas zimowej martwoty, dojrzewa dziecięce marzenie o podróży. Widok rozpalonego, „blaszanego piecyka”, źródła blasku i ciepła, skłania podmiot marzenia do rojeń o wyprawie w „nieznane pejzaże [...], pozbawione mokrego śniegu oraz wezbranej Uny" (Šehić, 2016, 171). Płomień bowiem, jak dowodzi Gaston Bachelard, jest ,jednym z największych twórców obrazu. Płomień zmusza naszą wyobraźnię do pracy. [...] Każde marzenie przy płomieniu cechuje zachwyt. Ktokolwiek marzy o płomieniu, wpada w stan marzenia pierwotnego" (Bachelard, 1996, 7-8). W pamięci hipnotyka powracają także obrazy przedmiotów intymnych, które posiadają wymiar głębi i ,wewnętrzności” (Bachelard, 1976, 241). Wszelkie bowiem szafy, sekretery, kufry, szkatuły, szuflady, kryjówki czy skrzynie stają się źródłem „pamięci o niepamiętanym” (Bachelard, 1976, 240). W powieści Šehicia wzmiankowane „byty głębi” odkrywają przed marzycielem tajemnicę swojej zawartości, co ilustruje cytat:

W kredensie: szklane naczynia, dokumenty z pieczęcią Królestwa Serbów, Chorwatów i Słoweńców, złota biżuteria, butelki z ziołową rakiją do leczniczych okładów nie przejmują się zbytnio naszym pojęciem czasu. Podobnie jak zamknięta na klucz szuflada, do której udawało mi się od czasu do czasu zajrzeć, na przykład wtedy, gdy babcia wyciągała z niej złoty pierścionek z opalem. Odwracałem go do żyrandola i ukrytej żarówki, a kamień tuż przed moimi oczyma mienił się kolorami (Šehić, 2016, 171). 
Definiowana jako sfera życia nieświadomego, piwnica występuje zaś jako skupisko porzuconych przedmiotów oraz miejsce występowania fauny chtonicznej ${ }^{15} \mathrm{w}$ postaci ,purpurowych robaków” (Šehić, 2016, 53).

Wśród wskrzeszonych przez hipnotyka świetlistych śladów pamięciowych wymienić także należy „zrośnięte” z domem dzieciństwa środowisko wodne w postaci rzek, ich dopływów, meandrów, koryt, łożysk, ujść, źródeł, nurtów, prądów, wirów, a także „progów, [...] strug, głębińców, płycizn, zieleńców i spokojnych zakątków" (Šehić, 2016, 143). Rzeka i jej nadbrzeżne otoczenie, z niespotykaną bujnością świata roślinnego, przeobraża się w „twierdzę”, schronienie marzyciela oraz w locus amoenus, tj. miejsce bezpieczne, będące wyłącznie źródłem doznań przyjemnych. W wydobytych z pamięci obrazach wody rzeczne jawią się także jako substancja dynamiczna i niszcząca. Podlegająca rytmowi zmian pór roku rzeka nabrzmiewa, wzbiera, występuje z brzegów, podmywa ludzkie siedziby, zabiera ze sobą szczątki organiczne oraz porzucone przedmioty. Bezpostaciowy, niezróżnicowany i pozbawiony wymiaru temporalnego żywioł akwatyczny przywodzi również na myśl potencjalność wszystkich form bytu oraz miejsce symbolicznej przemiany bohatera poprzez zanurzenie się w wodzie, co oznacza zawsze ,powrót do stanu sprzed ukształtowania w jego podwójnym sensie śmierci i rozkładu, ale również odrodzenia i ponownego krążenia, gdyż zanurzenie pomnaża potencjał życia" (Cirlot, 2006, 457; Kowalski, 2002, 37). Tego rodzaju doświadczenie staje się udziałem podmiotu hipnotyzowanego, co potwierdza fragment:

Logika nakazuje, abym na początku powrócił tam, skąd przybyliśmy. W wodę, z której jesteśmy stworzeni. [...] A może naprawdę rodzimy się za każdym razem, gdy zanurzamy się w wodzie. Powracamy wówczas do grot prapoczątków, przyozdobionych morskimi algami, powraca tam nasza pamięć. Być może nasze komórki, jeszcze zanim ze skóry odpadną nam łuski, zanim ponownie będziemy pełznąć przez mieliznę w stronę strasznego lądu, przypomną sobie kształty, w których niegdyś występowały. Kąpiel staje się wtedy synonimem zmartwychwstania oraz nowego życia. [...] Trudno podważyć fakt, że życie powstało z wody. Bliskości z życiodajną siłą natury, którą odczuwam podczas skoku w jej fale, nie sposób porównać z innymi darami ziemi. To wejście w wodę, kiedy ona i ty stajecie się jednym ciałem... Za tym tęsknią kochankowie wszystkich epok (Šehić, 2016, 28, 137).

${ }^{15}$ Zamieszkujące przestrzenie dolnego świata robaki postrzegane są kulturze tradycyjnej oraz tradycji literackiej jako istoty zaświatowe „,najemnicy śmierci i diabła, nosiciele plag i chorób oraz „wysłannicy obcych i wrogich sił”. Na ten temat v. Kawa, 2011, 69-193. 
W hipnotycznej regresji rzeka Una staje się także skupiskiem różnorodnych form nawodnego i podwodnego życia. W przywołanym z pamięci obrazie świata ichtiofauny napotykamy „szybsze od strzały szczupaki”, „wąsate brzany”, „płotki i karpie - wodne krowy”, „lipienie - rybie torpedy”, „pstrągi - niezależnych władców kaskad i strug rzecznych” a także młodziczki, głowacze, węgorze i klenie (Šehić 2016, 27). Symbolizujące płodność, czystość duchową i fizyczną, a także pierwotne wody, z których zrodziło się życie (Cooper, 1998, 232, 237), ryby jawią się w marzeniu hipnotyka jako istoty bezgranicznie wolne i zniewalające swym zewnętrznym pięknem. Będące źródłem doznań estetycznych „zaglądanie w ryby” przeobraża się szybko w łowiecką pasję, która „stymuluje zdolności strategiczne [człowieka]: czujność, upór, bitność, odwagę, spryt, umiejętność zastawiania zasadzki, wabienia czy czyhania” (Morin, 1977, 91). Rybołówstwo umożliwia także rozpoznanie wodnego świata, czytanie wysyłanych przezeń bodźców i sygnałów. Jak przekonuje bowiem Ota Pavel, dziennikarz sportowy, pisarz i cierpliwy wędkarz, „do prawdziwej rzeki zagląda się jedynie wędką" (Pavel, 1988, 205).

W przywołanych w pamięci obrazach ważne miejsce zajmuje świat przyrody, którego bujność i witalizm przywodzi na myśl, by rzec słowami Brunona Schulza, ,wielką, pogańską orgię” (Schulz, 1997, 10). Wybujała natura (w utworze podlega ona zabiegowi symbolizacji i metaforyzacji), skupisko różnorodnych gatunków flory i fauny, staje się dla marzyciela azylem, obszarem wolności, zabawy i przygody. Ukryte w gąszczu zieleni kryjówki przypominają jako żywo loca amoena, a więc miejsca, by przywołać definicję Ernsta Curtiusa, ulubione, przyjemne, „piękne i ocienione, [...] położone naturalnie nad łączką lub strumieniem" (Curtius, 1997, 194-195). Tak definiowana przyroda dostarcza także licznych wrażeń zmysłowych:

Una i jej brzegi były moim schronieniem - niemożliwą do zdobycia zieloną twierdzą. Tutaj, pod gałęziami pokrywającymi się liśćmi, chowałem się przed ludźmi. Sam w ciszy, otoczony zielenią. Słyszałem jedynie bicie własnego serca, trzepot muszych skrzydeł i plusk ryby wyskakującej, a potem znów wracającej do wody. Nie żebym w ten sposób okazywał ludziom swoją nienawiść, po prostu lepiej się czułem wśród roślin i dzikich zwierząt. Od chwili, gdy wejdę w nadrzeczne zarośla, nic złego nie może mi się już przydarzyć. [...] Rośliny stanowiły dla mnie tajemnicę świata. Wyniosła arystokracja chlorofilu, niewierząca w życie pozagrobowe. [...] Krucha, soczysta esencja - można się było wedrzeć w nią jedynie mechanicznie, rozprowadzając po dłoniach 
zielony sok, tę krew, o którą one nie dbały i którą tak chętnie puszczały, w wiosennym przebudzeniu były bowiem wieczne i niezniszczalne (Šehić, 2016, 31-32).

Ukazana w utworze przyroda podlega kosmicznym rytmom zmieniających się pór roku. Wiosna, moment budzenia się życia i początek wzrastania, jest czasem „cudu”, karnawału, podczas którego mają miejsce błyski, eksplozje oraz powszechne ,pijaństwo na niebie i ziemi” (Šehić, 2016, 21). Lato przynosi zaś blask roślin i ciepłe deszcze, które „mącą rozum” (Šehić, 2016, 34). Jesień, pora melancholii i zamierania, odznacza się natomiast chłodem ,porannych mgieł i rozdygotanych zmierzchów” (Šehić, 2016, 32). W okresie zimowej stagnacji i martwoty ${ }^{16}$ dom nad Uną przeobraża się w grobowiec, miejsce marzeń, lektury i niecierpliwego wyczekiwania na przebudzenie i tryumfalny powrót sił wegetacji. Należy dodać, że na bogactwo natury składają się także barwy nieba, wędrówki słońca i fazy księżyca, a także różnorodne typy opadów atmosferycznych, wiatrów, chmur (w powieści stworzono cały ich katalog), burz oraz ciał astralnych.

W regresywnych obrazach powracają także osiowe figury wczesnego okresu życia. Do grupy tej narrator-bohater zalicza, obdarzone niezwykłymi cechami i umiejętnościami, postaci: matki, babki, dziadka Asima, „zbawcy gołębi”, starej wdowy o tajemniczo brzmiącym przydomku Bułgarzyca, pana Emila, z pochodzenia Czecha, który, zmuszał węże do opuszczenia ogniska domowego wyłącznie przy pomocy magicznych formułek” (Šehić, 2016, 102), Mirdala Terzicia, „czarodzieja” i znawcy przyrody oraz serdecznego przyjaciela, który zginął w tragicznych okolicznościach, tuż po zakończeniu działań wojennych.

Na pierwotne, jasne obrazy początków życia mimowolnie nakłada się jednak ciemna smuga traumatycznych wspomnień wojennych. Źródłem wszelkich treści tłumionych i wypartych czyni hipnotyk figurę Gargana. Ten demoniczny osobnik o skórze śniadej, ,czarnych jak sadza włosach i płomiennych oczach" reprezentuje bez wątpienia ciemną stronę osobowości podmiotu hipnotyzowanego. Gargano, to ,impertynenckie stworzenie, lojalne wobec mroku i przygód, [...] okrutny i sprytny złoczyńca" (Šehić, 2016, 66, 68), budzi asocjacje z Jungowskim archetypem Cienia. Zdaniem twórcy psychologii głębi Cień definiowany jako „ciemne, gorsze

${ }^{16}$ Anna Zadrożyńska $(1985,41)$ twierdzi, że nadchodzenie zimy jest w „kulturowym sensie równoważne końcowi świata i kataklizmowi życia”. 
cechy charakteru" zakłóca ${ }^{17}$ funkcjonowanie ego, a więc ważnego składnika jednostkowej świadomości (Jung, 1993, 68, 69). Między „ja” i Cieniem istnieje nieustanna relacja napięcia. Ego bowiem blokuje w człowieku tzw. złe skłonności. Jako swoista „bomba psychiczna”, gotowa wybuchnąć w każdym momencie (Dudek, 2002, 233), Cień gromadzi zatem wszelkie treści niezrozumiałe, tłumione, wypierane czy odszczepione od świadomości. Wobec słabości ,ja” i braku zasad moralnych zgromadzona w sferze nieświadomego negatywna energia emocjonalna może znaleźć swoje ujście w aktach autodestrukcji oraz słownej bądź fizycznej przemocy wobec innych ludzi. Do podstawowych personifikacji Cienia zaliczyć należy figury (w tej grupie znajduje się niechybnie Šehiciowski Gargano): smoka, dzikich zwierząt, czarownicy czy złego ducha. Wśród zawodów, które „przyciągają” Cień, wymienić zaś trzeba profesję kata, złodzieja, mordercy, policjanta czy żołnierza (Dudek, 2002, 239, 251).

To właśnie były wojownik, osoba kierująca się w swych działaniach „etyką Cienia”, przemawia do ludzi o „pokojowo nastawionych sercach" (Šehić, 2016, 69) w trakcie seansu hipnotycznego. Wypowiedzenie tego, co stłumione, prawdziwej esencji duchowego mroku, stanowi próbę „uwolnienia się od form i treści wojennych obrazów” (Šehić, 2016, 65). Opowieść o traumie przybiera postać „telegramu z mrocznych wód”, którego treść zdominowana zostaje przez obrazy przyrody brutalnie przeobrażonej przez ,wojenne dzieła i wojskową logikę ludzkiego kosmosu" (Šehić, 2016, 70). W języku Gargana-Cienia wyartykułowana zostaje także historia jednostkowej odrazy, melancholii oraz pierwotnego, ludzkiego lęku przed nocą, śmiercią, wilgocią i rozkładem cielesnej formy. Mroczna historia obejmuje również fakt zagłady nadrzecznego miasta. Niegdysiejszy Mały Paryż (Bihać), przestrzeń „starego, lepszego [i] piękniejszego życia" (Šehić, 2016, 87) przeistacza się, wskutek celowych działań destrukcyjnych człowieka, w pozbawioną znaków autentycznego trwania ziemię jałową, „widmo” oraz „poczekalnię na śmierć w drugiej klasie”

${ }^{17}$ Jak zauważa Carl Gustav Jung (1995, 99), „nie ma żadnej wątpliwości co do tego, że człowiek - jako całość - nie jest tak dobry, jak sobie wyobraża, czy jakim chce być. Za każdym podąża jego cień [podkr. M.B.] - w im mniejszym stopniu zespolony ze świadomym życiem jednostki, tym ciemniejszy, tym bardziej gęsty. [...] Nosimy ze sobą naszą przeszłość - człowieka prymitywnego i niższego ze wszystkimi jego pożądaniami i emocjami. Tylko poważny wysiłek może nas uwolnić od tego brzemienia". 
(Šehić, 2016, 88). Wyjściu ze stanu hipnozy towarzyszy rozkojarzenie, dezorientacja, ociężałość oraz błądzenie, co potwierdza cytat:

\begin{abstract}
Z hipnotycznego transu wydobyłem się sam, bez udziału widocznego bodźca zewnętrznego. Moje oczy wypełnione były miksturą z ciemności. Przez chwilę nie mogłem się odnaleźć w tym mroku. [...] Poruszałem się po omacku jak lunatyk. [...] Nie mógł to być somnambulizm, moja świadomość pracowała na pełnych obrotach. [...] Któż wie, gdzie się znalazłem, w jakiej czasoprzestrzeni, podczas pobytu w mrocznej sali kinowej straciłem poczucie zewnętrznego czasu, a przestrzeń mogła być czyjąś zaślinioną gardzielą (Šehić, 2016, 138).
\end{abstract}

Doświadczenie hipnozy pozwala jednak bohaterowi „zamknąć” indywidualną ranę oraz ostatecznie „odkleić się od Gargana i jego zaraźliwych myśli" (Šehić, 2016, 88).

Książka o Unie stanowi ważny głos twórcy należącego do generacji porażonej doświadczeniem wojny (pregažena generacija). Utwór stanowi przede wszystkim próbę artystycznego przepracowania zdarzeń traumatyzujących, które stały się udziałem pisarza. Zabliźnieniu wojennej rany służy ukazany w powieści seans hipnotyczny, podczas którego narrator-bohater, alter ego artysty, odbywa, w ramach regresji wieku, wyobrażoną podróż do krainy dzieciństwa. Wizualne i słowne przywołanie przyjemnych śladów pamięciowych w postaci obrazów opiekuńczych mocy, domu rodzinnego, artefaktów nostalgicznych oraz żywiołu akwatycznego posiada w badanym utworze wymiar terapeutyczny. Leczenie wojennej traumy prowadzi także do rozpoznania i werbalizacji treści Cienia indywidualnego, który reprezentuje mroczny aspekt ludzkiej osobowości.

\title{
Literatura
}

Assman, J. (2015). Pamięć kulturowa. Pismo, zapamiętywanie i polityczna tożsamość w cywilizacjach starożytnych. Przeł. A. Kryczyńska-Pham. Wstęp i red. naukowa R. Traba. Warszawa: Wydawnictwo Uniwersytetu Warszawskiego.

Augustynek, A. (1989). Ksztaltowanie specyficznych zachowań ludzkich. Sugestia i hipnoza. Kraków: Wydawnictwo Naukowe Wyższej Szkoły Pedagogicznej.

Bachelard, G. (1975). Wyobraźnia poetycka. Wybór pism. Przeł. H. Chudak, Warszawa: PIW.

Bachelard, G. (1976). Poetyka przestrzeni: szuflada, kufry i szafy. „Pamiętnik Literacki” LXVII, z.1, s. 233-243. 
Bachelard, G. (1979). Dom od piwnicy aż po strych. Znaczenie schronienia. Przeł. M. Ochab. „Punkt” nr 8, s. 136-155.

Bachelard, G. (1996). Płomień świecy. Przeł. J. Rogoziński, Gdańsk: słowo/obraz/terytoria.

Bachelard, G. (1998). Poetyka marzenia. Przeł. L. Brogowski. Gdańsk: słowo/obraz/ terytoria.

Baudelaire, C. (1997). Moje obnażone serce, w. XXVI. Przeł., wstępem i przypisami opatrzył A. Kijowski. Wrocław: Pracownia Borgis.

Bogdanović, B. (1997). Rytualne zabijanie miasta. Przeł. K. Bąk. „Krasnogruda” nr 6, s. $27-33$.

Caillois, R. (1973). Żywioł i ład. Wyboru dokonał A. Osęka. Przedmową opatrzył M. Porębski. Przeł. A. Tatarkiewiczowa. Warszawa: PIW, s. 160-168.

Cirlot, J.E. (2006). Słownik symboli. Przeł. I. Kania. Kraków: Wydawnictwo „Znak”.

Cooper, J.C. (1998). Zwierzęta symboliczne i mityczne. Przeł. A. Kozłowska-Ryś i L. Ryś. Poznań: Dom Wydawniczy „Rebis”.

Curtius, E. (1997). Literatura europejska i tacińskie średniowiecze. Tłum. i oprac. A. Borkowski. Kraków: Towarzystwo Autorów i Wydawców Prac Naukowych UNIVERSITAS.

Czermińska, M. (1978). Dom w autobiografii i w powieści o dzieciństwie. W: Przestrzeń i literatura. Studia pod red. M. Głowińskiego i A. Okopień-Sławińskiej. Wrocław: Zakład Narodowy im. Ossolińskich, s. 229-252.

Dudek, Z. (2002). Podstawy psychologii Junga. Od psychologii głębi do psychologii integralnej. Warszawa: Wydawnictwo „Eneteia” - Wydawnictwo Psychologii Kultury.

Eihenreich, B. (1997). Rytuaty krwi. Przeł. P. Kołyszko. Warszawa: Jacek Santorski \& Co. Eliade, M. (1996). Sacrum a profanum. O istocie religijności. Przeł. R. Reszke. Warszawa: Wydawnictwo KR.

Gusdorf, G. (1979). Warunki i ograniczenia autobiografii. Przeł. J. Barczyński, „Pamiętnik Literacki" LXX, z. 1, s. 261-278.

Jung, C.G. (1993). Archetypy i symbole. Pisma wybrane. Wybrał, przełożył i wstępem poprzedził J. Prokopiuk. Warszawa: „Czytelnik”.

Jung, C.G. (1995). Psychologia a religia. Przeł. J. Prokopiuk. Opracował R. Reszke. Warszawa: Wydawnictwo KR - Wydawnictwo „Wrota”.

Kaczorowski, A. (2008). Reinkarnacje w hipnoterapii. Doświadczenie poprzednich wcieleń i innych rzeczywistości w terapii hipnoza. Białystok: Studio Astropsychologii.

Kawa, M., (2011). Ten, który toczy nasze dusze i ciała... Robak i robactwo w kulturze i literaturze. Toruń: Wydawnictwo Adam Marszałek.

Kępiński, A. (2004). Rytm życia. Kraków: Wydawnictwo Literackie.

Kodrić, S. (2012). Postkanonski kulturnomemorijski makromodel. W: S. Kodrić. Književnost sjećanja: Kulturno pamćenje i reprezentacija prošlosti u novijoj bošnjačkoj književnosti. Ur. S. Halilović. Sarajevo: Slavistički komitet, s. 174-201.

Kowalski, P. (1998). Dom. W: P. Kowalski. Leksykon. Znaki świata. Omen, przesad, znaczenie. Warszawa - Wrocław: PWN. 
Kowalski, P. (2002). Woda żywa. Opowieść o wodzie, zdrowiu, higienie i dietetyce. Wrocław: Ossolineum.

Kristeva, J. (2007). Potęga obrzydzenia. Esej o wstręcie. Przeł. M. Falski. Warszawa: Wydawnictwo Uniwersytetu Jagiellońskiego.

Kropikiewicz, H. (1992). Hipnoza i sugestia. Poznań: Wydawnictwo „Andromeda”.

Leeuw, G. van der (1978). Fenomenologia religii. Przeł. J. Prokopiuk. Warszawa: „Książka i Wiedza”.

Levine, P.A., Frederic A. (2012). Obudźcie tygrysa. Leczenie traumy. Przeł. B. Jarzębska-Ziewiec. Warszawa: „Czarna Owca”.

Lis-Turlejska, M. (2005). Traumatyczne zdarzenia i ich skutki psychiczne. Warszawa: Instytut Psychologii PAN.

Maruszewski, T. (2005). Pamięć autobiograficzna. Gdańsk: Gdańskie Wydawnictwo Psychologiczne.

Menninghaus, W. (2009). Wstręt. Teoria i historia. Przeł. G. Sowiński, Warszawa: Towarzystwo Autorów i Wydawców Prac Naukowych UNIVERSITAS.

Morin, E. (1977). Zagubiony paradygmat - natura ludzka. Przeł. R. Zimand. Warszawa: PIW.

Olsen, B. (2018). Jak rzeczy pamiętają? W: Antropologia pamięci. Zagadnienia i wybór tekstów. Wstęp i red. P. Majewski i M. Napiórkowski. Warszawa: Wydawnictwo Uniwersytetu Warszawskiego, s. 85-96.

Pavel, O. (1988). Śmierć pięknych saren. Z języka czeskiego przełożyli A. Piotrowski i J. Waczków. Wstępem opatrzył A. Piotrowski. Katowice: Wydawnictwo: „Śląsk”.

Peterson, Z. (1994). Hipnoza. Między jawą a snem. Warszawa - Łódź: Wydawnictwo PWN.

Raljević, S. (2014). Čitanje rata u «Knjizi o Uni» Faruka Šehića. „Sarajevske sveske” (tema: Književnost u egzulu, prognanstvu i emigracji), br. 45-46. sveske-ba/en/ content/citanje-rata-u-knjizi-o-uni-faruka-sehicia/. 14.01.2019.

Roux, J.P. (2013). Krew. Mity, symbole, rzeczywistość. Przeł. M. Chrobak. Kraków: Wydawnictwo ,Znak”.

Sandauer, A. (1981). O ewolucji sztuki narracyjnej w XX wieku. W: Zebrane pisma krytyczne. Studia historyczne i teoretyczne, t. 2. Warszawa: PIW, s. 455-470.

Schulz, B. (1997). Sierpień. W: Sklepy cynamonowe. Warszawa: PIW.

Šehić, F. (2016). Książka o Unie. Przeł. A. Schreier. Wrocław - Stronie Śląskie: Biuro Literackie.

Tabaszewska, J. (2011). Trauma - kategoria estetyczna? W: Trauma, pamięć, wyobraźnia. Pod red. Z. Podniesińskiej i J. Wróbla. Kraków: Wydawnictwo Uniwersytetu Jagiellońskiego, s. 13-26.

Tischner, J. (1990). Filozofia dramatu. Wprowadzenie. Paryż: Sekretariat Misyjny.

Wolberg, L.R. (1975). Hipnoza. Przeł. Z. Stromenger. Warszawa: PWN.

Zadrożyńska, A. (1985). Powtarzać czas początku. O świętowaniu dorocznych świąt w Polsce, cz. 1. Warszawa: Wydawnictwo Spółdzielcze. 